\title{
Forest Canopy Changes in the Southern Amazon during the 2019 Fire Season Based on Passive Microwave and Optical Satellite Observations
}

\author{
Huixian Zhang ${ }^{1}$, Daniel Fiifi Tawia Hagan ${ }^{1}\left(\mathbb{D}\right.$, Ricardo Dalagnol $^{2}\left(\mathbb{D}\right.$ and Yi Liu ${ }^{1, *(D)}$ \\ 1 School of Geographical Sciences, Nanjing University of Information Science and Technology, \\ Nanjing 210044, China; h.x.zhang@nuist.edu.cn (H.Z.); dans7messiah@nuist.edu.cn (D.F.T.H.) \\ 2 Earth Observation and Geoinformatics Division, National Institute for Space Research-INPE, \\ São José dos Campos 12227-010, Brazil; ricardo.silva@inpe.br \\ * Correspondence: yi.liu@nuist.edu.cn; Tel.: +86-25-5823-5190
}

check for updates

Citation: Zhang, H.; Hagan, D.F.T.; Dalagnol, R.; Liu, Y. Forest Canopy Changes in the Southern Amazon during the 2019 Fire Season Based on Passive Microwave and Optical Satellite Observations. Remote Sens. 2021, 13, 2238. https://doi.org/ $10.3390 /$ rs13122238

Academic Editors: Luis A. Ruiz, Ioannis Gitas, Arnaud Mialon,

Nemesio Rodriguez-Fernandez, Mariette Vreugdenhil, Tianjie Zhao and Roberto Fernández Morán

Received: 12 April 2021

Accepted: 4 June 2021

Published: 8 June 2021

Publisher's Note: MDPI stays neutral with regard to jurisdictional claims in published maps and institutional affiliations.

Copyright: (c) 2021 by the authors. Licensee MDPI, Basel, Switzerland. This article is an open access article distributed under the terms and conditions of the Creative Commons Attribution (CC BY) license (https:/ / creativecommons.org/licenses/by/ $4.0 /)$.

\begin{abstract}
Canopy dynamics associated with fires in tropical forests play a critical role in the terrestrial carbon cycle and climate feedbacks. The aim of this study was to characterize forest canopy dynamics in the southern Amazon during the 2019 fire season (July-October) using passive microwave-based vegetation optical depth (VOD) and three optical-based indices. First, we found that precipitation during July-October 2019 was close to the climatic means, suggesting that there were no extreme hydrometeorological events in 2019 and that fire was the dominant factor causing forest canopy anomalies. Second, based on the active fire product (MCD14ML), the total number of active fires over each grid cell was calculated for each month. The number of active fires during the fire season in 2019 was above average, particularly in August and September. Third, we compared the anomalies of VOD and optical-based indices (the normalized difference vegetation index (NDVI), the enhanced vegetation index (EVI), and the normalized burn ratio (NBR)) against the spatiotemporal distribution of fires during July-October 2019. Spatially, the location with a concentrated distribution of significant negative VOD anomalies was matched with the grid cells with fire activities, whereas the concentrated distribution of strong negative anomalies in optical-based indices were found in both burned and unburned grid cells. When we focused on the temporal pattern over the grid cells with fire activity, the VOD and the optical-based indices behaved similarly from July to October 2019 , i.e., the magnitude of negative anomalies became stronger with increased fire occurrences and reached the peak of negative anomalies in September before decreasing in October. A discrepancy was observed in the magnitude of negative anomalies of the optical-based indices and the VOD; the magnitude of optical-based indices was larger than the VOD in August-September and recovered much faster than the VOD over the grid cells with relatively low fire activity in October. The most likely reason for their different responses is that the VOD represents the dynamics of both photosynthetic (leaf) and nonphotosynthetic (branches) biomass, whereas optical-based indices are only sensitive to photosynthetic (leaf) active biomass, which recovers faster. Our results demonstrate that VOD can detect the spatiotemporal of canopy dynamics caused by fire and postfire canopy biomass recovery over high-biomass rainforest, which enables more comprehensive assessments, together with classic optical remote sensing approaches.
\end{abstract}

Keywords: the Amazon; fire; vegetation optical depth; optical indices; canopy changes

\section{Introduction}

The Amazon rainforest is a species-rich biome and is a major component of the Earth's ecosystem [1]. It is an important tropical carbon sink in the global carbon cycle [2]. However, because of deforestation, the expansion of agricultural activities, and climate factors in the Amazon, forest fires occur every year [3,4]. Fire is a dominant disturbance that changes the biomass, the ecosystem structure, and the species composition [5]. Fires 
lead to significant vegetation changes and an increase in carbon and aerosol emissions, which greatly impacts the carbon cycle and climate conditions over long periods at both regional and global scales [1,6,7].

In recent years, in addition to deforestation, the increased frequency of extreme droughts in the Amazon has also increased fire incidence and the associated greenhouse gas emissions [6,8,9], which reflects the increased vulnerability of Amazon forest to droughts [10]. Additionally, the Amazon region is projected to have continuous warming, according to climate-carbon cycle projections [11], an increase in the frequency and severity of extreme events, as well as an extended duration and increasing dryness during dry seasons in non-drought years throughout the 21st century [11-14]. The synergy between extreme drought and human activities creates the conditions for large-scale forest fires in the Amazon [15,16], which produces a dual threat of fires and climate change in this century [1]. Therefore, a better understanding of the vegetation dynamics caused by fires during the fire season would help us to improve our regional and global assessments of carbon emissions, carbon cycle variability, and associated climate feedbacks.

Optical remote sensing data and indices such as the enhanced vegetation index (EVI), the normalized difference vegetation index (NDVI), and the normalized burn ratio (NBR) have been widely used to monitor the vegetation changes caused by fires because of their real-time and wide-range monitoring [17]. Several studies have used high-resolution satellite imagery with no cloud and haze contamination, from a single date or over multiple years, to investigate canopy changes caused by fires in some areas of the Amazon $[5,18,19]$. However, their results are mainly representative of their study area and may not translate to the whole Amazon region [19]. Moreover, single-date or infrequent satellite data application may be a potential source of assessment error because of rapid canopy closure and regeneration, leading to an underestimate of canopy damage [20,21]. Moreover, vegetation changes caused by fire in the understory of a forest might not be detected because optical indices mainly reflect the information of canopy overstorey [22]. No study, to the best of our knowledge, has used high temporal frequency images (several dates of satellite data from a year) to characterize the canopy dynamics caused by fire for the whole Amazon region [20,23]. The main reason may be that higher clouds and aerosol concentration in the Amazon restrict the use of optical satellite data at high temporal resolutions.

Satellite passive (radiometer) and active (radar) microwave remote sensing are minimally affected by atmospheric conditions in tropical regions because of the long microwave wavelength and its strong penetration capacity [24-26], which can be used as one of the means for monitoring vegetation changes $[27,28]$. The choice of observations from active and passive microwave remote sensing in research depends on the objects of study in research. Radar backscatter data is usually used to assess the vegetation changes in a fine spatial scale $[26,27,29]$, whereas radiometer-derived data is chosen to study the regionalscale $[30,31]$. The passive microwave-based vegetation optical depth (VOD) is a vegetation attenuation parameter for retrieving soil moisture, which is linearly correlated with vegetation water content and above-ground biomass comprising the leaf and woody parts $[25,30]$. There is little evidence for the signal saturation of the VOD in higher biomass density regions [31]. Therefore, the VOD can provide global, repeated vegetation observations with high temporal resolution and has been used to monitor large-scale vegetation changes, providing an alternate source of information to monitor vegetation changes compared to optical vegetation products [25]. The VOD derived from different spectral bands (L, C, X, and $\mathrm{Ku}$ ) have inconsistent sensitivities to the canopy biomass [30]. Longer wavelength VOD retrievals are more sensitive to a larger bulk of vegetation biomass and deeper vegetation layers. Therefore, there may be some difference in the same vegetation changes assessed by various VOD products [32]. Currently, the VOD has been used to monitor vegetation phenology [33], long-term vegetation change [34], vegetation's response to drought [35,36], vegetation changes associated with fire [32,37], forest loss [38], as well as aboveground biomass carbon assessment $[39,40]$. The VOD retrieved from shorter wavelengths are more 
widely used in monitoring vegetation changes relative to VOD-L [41]. VOD-C is sensitive to both leaf and woody vegetation, which has been proved by previous studies [36,42].

So far, the VOD has limited use in monitoring the vegetation variations associated with forest fires [32], likely because of its commonly coarse resolution of $0.25^{\circ}$. Jones et al. [32] used NDVI and VOD-X with a $0.25^{\circ}$ spatial resolution to estimate boreal forest canopy recovery after fire and found that the recovery period indicated by VOD was longer than that found by NDVI. More recent developments on the passive microwave-based VOD that derived from the $\mathrm{C}$ band (VOD-C) has led to it being enhanced to a spatial resolution of $0.1^{\circ}$, which can capture more spatial information [43]. Liu et al. [35] used it to investigate the Amazon rainforest canopy dynamic during the 2005 and 2010 droughts and found canopy growth enhanced in the onset of drought (May-July), and canopy senescence was observed during the peak of the drought (August-November). Chen et al. [37] combined it with various datasets and proved that the $0.1^{\circ}$ VOD could estimate the vegetation change caused by fire in Australian tropical savannas in a timely way. Besides, there are few studies using a $0.25^{\circ}$ VOD to identify canopy dynamics affected by fire. The application of the VOD with an enhanced spatial resolution is even less used in tropical forests with highly dense vegetation. Hence, the potential of the VOD at a high $\left(0.1^{\circ}\right)$ resolution to study tropical forest canopy dynamics, especially to understand the effects of fire on the canopy, urgently needs to be investigated. Whether a $0.1^{\circ}$ VOD can capture more detailed information about canopy dynamics affected by fires relative to a $0.25^{\circ} \mathrm{VOD}$ also requires examination.

The southern Amazon fires of 2019 can be considered as an ideal experiment to test the capacities of the VOD-C to assess fire-driven canopy dynamics because of the fact that the region did not experience extreme hydrometeorological events [44] and because it, unfortunately, has suffered one of the highest fire activities in recent decades [45]. The primary objective of this study was to assess the potential of the passive microwavebased VOD derived from $6.93 \mathrm{GHz}$ observations of the Advanced Microwave Scanning Radiometer 2 (AMSR2) to characterize forest canopy dynamics during the 2019 fire season in the southern Amazon, combined with a series of optical-based indices (EVI, NDVI, and $\mathrm{NBR}$ ) and precipitation and fire products. A comparison of these datasets can reveal the consistency and the difference between information indicated by the VOD and optical indices. Furthermore, this study could not only identify the potential of the VOD for estimating vegetation change caused by fires in high biomass density forests but also the potential of a synergistic application between the VOD and optical-based indices, which can provide a more comprehensive understanding of rainforest dynamics.

\section{Materials and Methods}

\subsection{Satellite-Based Datasets}

In this study, we used the $500 \mathrm{~m}$ MODIS land cover product (MCD12Q1, v6) based on the International Geosphere-Biosphere Programme (IGBP) classification of 2019 and the $30 \mathrm{~m}$ land cover product from the Map Biomass dataset (collection 5) for 2019 to define the perimeter of the forest in the southern Amazon (below 2.5 S, see Figure 1), where increasing fires in 2019 caused widespread concern [46]. The Map Biomass dataset is produced by the Brazilian Annual Land Use and Land Cover Mapping Project (https:/ / mapbiomas.org/colecoes-mapbiomas-1?cama_set_language=pt-BR, accessed on 16 March 2021), which was used to delineate the forest distribution over Brazilian biomes, and the rest of the southern Amazon forest distribution was depicted by MCD12Q1. Of the southern Amazon rainforest, $63.3 \%$ is covered by forests, while the other land cover types are savannah, pasture, grassland, and cropland, which are mainly distributed over the margin of the southern Amazon region. The wet season spans from November to June, and the dry season is from July to September according to the season cycle of precipitation [47]. 


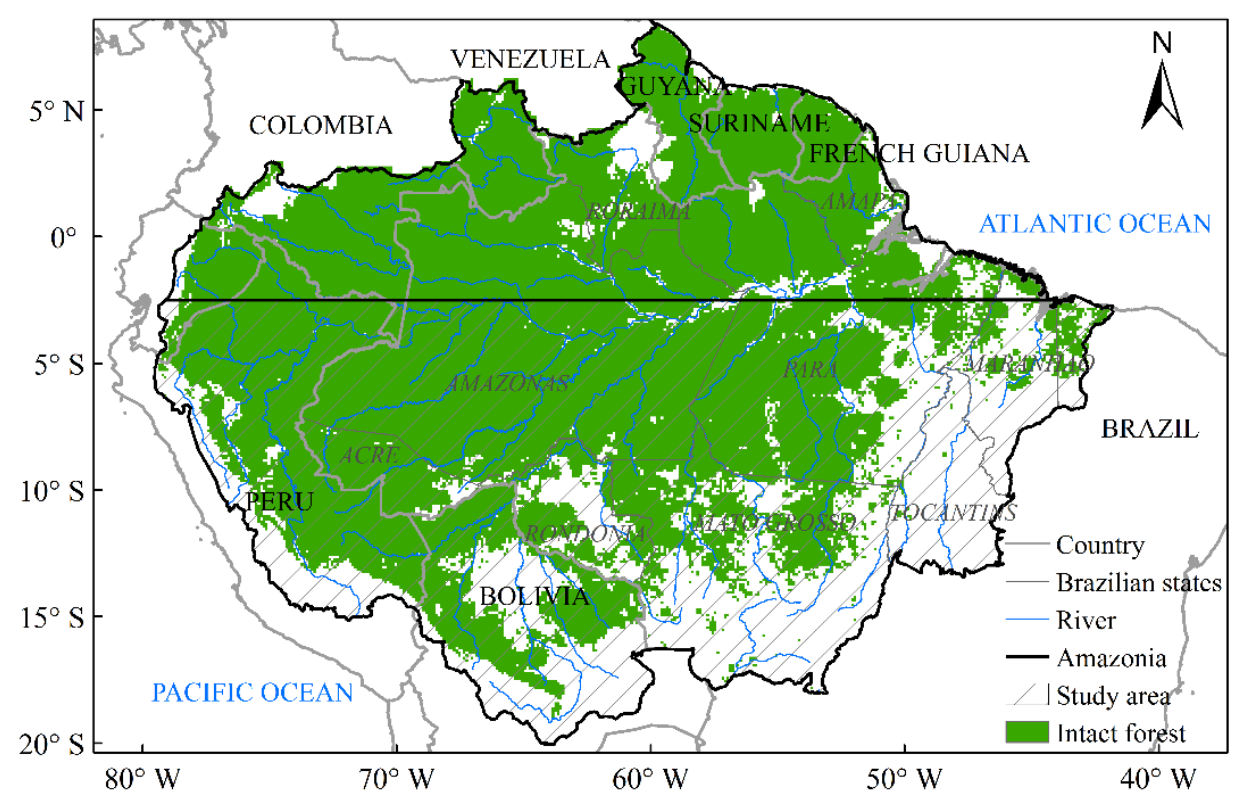

Figure 1. Spatial distribution of intact forest in the Amazon with $0.1^{\circ}$ spatial resolution in 2019. Intact forest means that the fraction of forest cover was greater than or equal to $50 \%$ in one $0.1^{\circ}$ grid cell that was defined as forest. Intact forest below $2.5^{\circ} \mathrm{S}$ over the southern Amazon was the study area of this paper.

We utilized the VOD and optical satellite vegetation data to characterize the rainforest canopy dynamics. The VOD data were derived from passive microwave observations of the Advanced Microwave Scanning Radiometer 2 onboard the Global Change Observation Mission-Water (GCOM-W) satellite that is operated by the Japan Aerospace Exploration Agency (JAXA). The land parameter retrieval model (LPRM) algorithm [48-50] was used to retrieve the VOD based on the AMSR2 L3 daily brightness temperature (TB). The AMSR2 L3 TB was produced by JAXA and can be freely downloaded from the GCOM-W1 Data Providing Service, which is available from 3 July 2012 until the present. The AMSR2 has an equator-crossing orbit of 1:30 am (descending) and 1:30 pm (ascending). The LPRM algorithm was applied to two different resolutions of C-band $(6.93 \mathrm{GHz})$ TB-descending paths to retrieve the VOD (VOD- $0.1^{\circ}$ and VOD- $0.25^{\circ}$ ). The VOD based on the nighttime TB was expected to be more reliable than that based on the daytime TB [35] because of the higher thermal equilibrium at night, which is beneficial for obtaining more accurate retrievals. Hence, VOD- $0.1^{\circ}$ and VOD- $0.25^{\circ}$ retrieved from the nighttime TB were both used in this study, with a focus on VOD- $0.1^{\circ}$. The optical satellite vegetation data used here included nadir-solar-normalized NDVI and EVI from the MANVI product at $1 \mathrm{~km}$ spatial resolution and monthly temporal aggregation [51]. This product was derived from the MODIS product MCD19A1 (v6) with corrections for atmospheric effects by the multi-angle implementation of atmospheric correction (MAIAC) algorithm [52]. The EVI was calculated by red, near-infrared, and blue bands, whereas the NDVI was obtained from the calculation between the near-infrared and red bands. The normalized burn ratio was also used to estimate vegetation changes. The NBR is a normalized ratio of (NIR SWIR)/(NIR + SWIR), where NIR and SWIR refer to the surface reflectance of near-infrared and short-wave infrared bands, respectively [53]. Surface reflectance was obtained from a 16-day composite product with a $0.05^{\circ}$ spatial resolution (MYD13C1, v6), which was derived from the MODIS sensor on board the Aqua satellite [54].

We used two types of fire monitoring products to characterize the 2019 fire situation: the active fire and the burned area products derived from the MODIS onboard the Terra and Aqua satellites. The MODIS active fire product (MCD14ML, v6) is a monthly fire location dataset at a $1 \mathrm{~km}$ spatial resolution. Each fire point records several details, including the geographic location, the date of occurrence, the detection confidence, the satellite that 
detected the fire, etc. The detection confidence range is between 0 and $100 \%$, which is an indicator of the quality of the fire pixels, and is classified into three classes: low confidence $(0-30 \%)$, nominal confidence (30-80\%), and high confidence (80-100\%). The nominal- and high-confidence fire pixels have lower errors of commission relative to low-confidence fire pixels (see the user guide on https:/ / modis-fire.umd.edu/files/MODIS_C6_Fire_User_ Guide_C.pdf (accessed on 16 March 2021)). The MODIS burned area product (MCD64A1, v6) is a global monthly dataset containing burn dates and quality information for each burned pixel at a $500 \mathrm{~m}$ spatial resolution [55]. Additionally, precipitation from the global precipitation measurement [56] was used to judge whether the 2019 southern Amazon had been through a drought event.

All datasets used in the study cover the period from January 2012 to December 2019, except the VOD, which covers the period from July 2012 to now. More detailed information about these datasets is given in Table 1.

Table 1. Satellite datasets used in the study.

\begin{tabular}{ccc}
\hline Variable Name & Product Name & $\begin{array}{c}\text { Original Spatial and } \\
\text { Temporal Resolution }\end{array}$ \\
\hline Land cover type & $\begin{array}{c}\text { MCD12Q1, v6; } \\
\text { Map biomass product }\end{array}$ & $500 \mathrm{~m}$, year; 30 m, year \\
\hline $\begin{array}{c}\text { Vegetation optical depth } \\
\text { (VOD) }\end{array}$ & $\begin{array}{c}\text { Retrieved by land parameter } \\
\text { retrieval model (LPRM) based on } \\
\text { AMSR2 L3 TB }\end{array}$ & $0.25^{\circ} / 0.1^{\circ}$, twice per day \\
\hline $\begin{array}{c}\text { Enhanced vegetation index } \\
\text { (EVI) }\end{array}$ & MANVI & $1 \mathrm{~km}$, monthly \\
\hline $\begin{array}{c}\text { Normalized difference } \\
\text { vegetation index (NDVI) }\end{array}$ & MANVI & $1 \mathrm{~km}$, monthly \\
\hline Active fire & MCD14ML, v6 & $1 \mathrm{~km}$, monthly \\
\hline Burn area & MCD64A1, v6 & $500 \mathrm{~m}$, monthly \\
\hline $\begin{array}{c}\text { Normalized burn ratio } \\
\text { (NBR) }\end{array}$ & $\begin{array}{c}\text { Derived from surface reflectance } \\
\text { based on MYD13C1 }\end{array}$ & $0.05^{\circ}, 16$-day \\
\hline Precipitation & GPM_3IMERGM & $0.1^{\circ}$, monthly \\
\hline
\end{tabular}

\subsection{Data Preprocessing}

We used an aggregation or bilinear interpolation to resample precipitation, fire products, and optical remote sensing data into a $0.1^{\circ}$ spatial resolution at a monthly timescale for a more direct comparison with VOD- $0.1^{\circ}$.

For delineating Amazonia forest distribution at $0.1^{\circ}$ grid cells, the evergreen broadleaf forest land cover type of MCD12Q1 and the forest formation, mangrove, and forest plantation land cover types of the Map Biomass dataset were considered. The forest cover datasets with high resolution were resampled to $0.1^{\circ}$ and $0.25^{\circ}$ spatial resolutions by calculating the proportion of forest type in each corresponding $0.1^{\circ} / 0.25^{\circ}$ grid cell. To minimize the influence of non-forest vegetation dynamics, the forest at a $0.1^{\circ} / 0.25^{\circ}$ grid cell was defined when the fraction of forest cover was greater than or equal to $50 \%$ (Figure 1 and Figure S1). The choice of the threshold value of forest cover, e.g., $50 \%, 60 \%, 70 \%$, and $80 \%$, did not essentially change the results of this study. For retaining the large sample size, the threshold value of $50 \%$ was chosen here.

MCD14ML's precision to detect active fires is mainly affected by cloudy conditions [8]. To guarantee the fewest number of false fire detections, only the high-confidence active fires (above the $80 \%$ confidence level) were used here to generate monthly active fire data in $0.1^{\circ} / 0.25^{\circ}$ grid cells by summing up the daily active fires at the $1 \mathrm{~km}$ original resolution within each grid cell. For MCD64A1, each pixel of $500 \mathrm{~m}$ masked as burned was considered as the burn area with $0.25 \mathrm{~km}^{2}$. The monthly burned area data at the $0.1^{\circ} / 0.25^{\circ}$ 
spatial resolution were obtained by counting the number of $500 \mathrm{~m}$ burned pixels within the corresponding $0.1^{\circ} / 0.25^{\circ}$ grid cells.

\subsection{Analysis Methods}

To understand the general condition of precipitation and fire incidence over intact southern Amazonian forest, we first characterized the seasonal cycle of precipitation and active fires over a study period. The study period chosen here was the overlapping period of all datasets used, i.e., 2012-2019. Moreover, we focused on the differences in precipitation, fire activities, and vegetation behaviours between 2019 and other non-drought years; therefore, drought years (2015 and 2016) and the study year 2019 were excluded from the reference period used for the calculation of season cycle. The seasonal cycle of precipitation was represented by the monthly averages during the reference period. To calculate the seasonal cycle of active fires, we first calculated the regional total number of active fires for each month and then we took the monthly average for the reference period. Furthermore, precipitation and fire incidences over the region were examined by computing the monthly anomalies of these variables in 2019, representing a departure from their seasonal cycle.

The standardized anomalies for each month were calculated for vegetation metrics (VM, including VOD, NDVI, EVI, and NBR) at each pixel to detect the vegetation variation in 2019, expressed as follows:

$$
\alpha=\frac{\bar{x}-m}{\sigma}
$$

where $\alpha$ is the standardized anomaly in $2019, \bar{x}$ is the actual value in 2019 , and the monthly long-term mean $(m)$ and standard deviation $(\sigma)$ were calculated over the reference period mentioned above. Pixels with standardized anomalies less than -1 (i.e., $<-1$ standard deviation (SD)) were defined as a canopy decrease relative to non-drought years. The nonparametric Wilcoxon signed-rank test was used to evaluate anomalies in 2019 that were statistically different from non-drought years at $p<0.05$ [57].

Furthermore, to investigate the impact of fire on the canopy dynamics, it was necessary to first extract the burned grid cells. The seasonal cycle of active fires showed that $86 \%$ of high-confidence active fire occurrences were distributed from July to October over the intact forest in the southern Amazon. Thus, we focused on July-October (the fire season) with high fire occurrences overlapping with the dry season (July-September). The canopy damage caused by fire may not recover too quickly because of the canopy growth limited by the hydrometeorological conditions during the dry season. Some burn areas with a high fire severity may never recover. There were multiple fires within each month in some burned grid cells with a $0.1^{\circ}$ spatial resolution. Therefore, canopy damage may increase continually during the fire season. We used the cumulative number of active fires from July to each month (active fires $>1$ ) to quantify fire density and identify the burned pixels for each month during the fire season. The method was also used to define the monthly accumulated burn area based on MCD64A1. Accordingly, a comparison of the spatial distribution of standardized anomalies of vegetation metrics from burned and unburned pixels was used to reveal the impact of the 2019 fires on canopy changes. The Wilcoxon rank-sum test was used to calculate the statistical significance of the anomalies' distribution between burned and unburned pixels $(p<0.05)[57,58]$.

To estimate the monthly canopy changes caused by fire, we classified the fire event into 10 levels based on a $10 \%$ interval according to the cumulative distribution function (CDF) of the monthly cumulative active fire data (Figure S2) and took the average of the standardized anomalies of vegetation metrics at the corresponding level. The Pearson correlation coefficients $(\gamma)$ between the mean number of active fires and the mean of standard anomalies at corresponding levels was calculated. Moreover, the standardized anomalies of the difference between the October and July vegetation metrics $\left(\Delta \mathrm{VM}=\mathrm{VM}_{\mathrm{Oct}}-\mathrm{VM}_{\mathrm{Jul}}\right)$ based on Equation (1) were calculated to monitor canopy changes during the fire season in 2019. Then, we calculated the mean of the standardized anomalies 
of $\Delta \mathrm{VM}$ at the corresponding fire level based on the whole fire season's cumulative active fires data.

\section{Results}

\subsection{Precipitation and Active Fires Anomalies in 2019}

There was a strong seasonal cycle of precipitation and active fires over the southern Amazon (Figure 2). Active fires started to increase with the decrease in precipitation from June and reached their peak in September (Figure 2). After the dry season, active fires decreased with increased precipitation in October. The precipitation anomalies in 2019 showed that there was no significant difference between 2019 and the non-drought years. Before the dry season, the precipitation anomalies were within the standard deviation in each month, except in April. During the dry season, the precipitation anomalies of August and September were negative but just exceeding 0-1.5 standard deviations. However, the number of active fires was increased by July 2019 compared with the non-drought years. In August 2019, the number of active fires increased intensively—nearly three times higher than the non-drought years. Even though active fires decreased in September 2019, the number of active fires surpassed that in the non-drought years ( 0.88 standard deviation). The number of active fire incidences in October 2019 was similar to that of the non-drought years. Almost $90 \%$ of high-confidence active fires in 2019 occurred during the fire season. During the fire season, $90 \%$ of the total high-confidence active fires were found from July to September and $83 \%$ from August to September, which suggested that fires mainly occurred in August-September 2019.
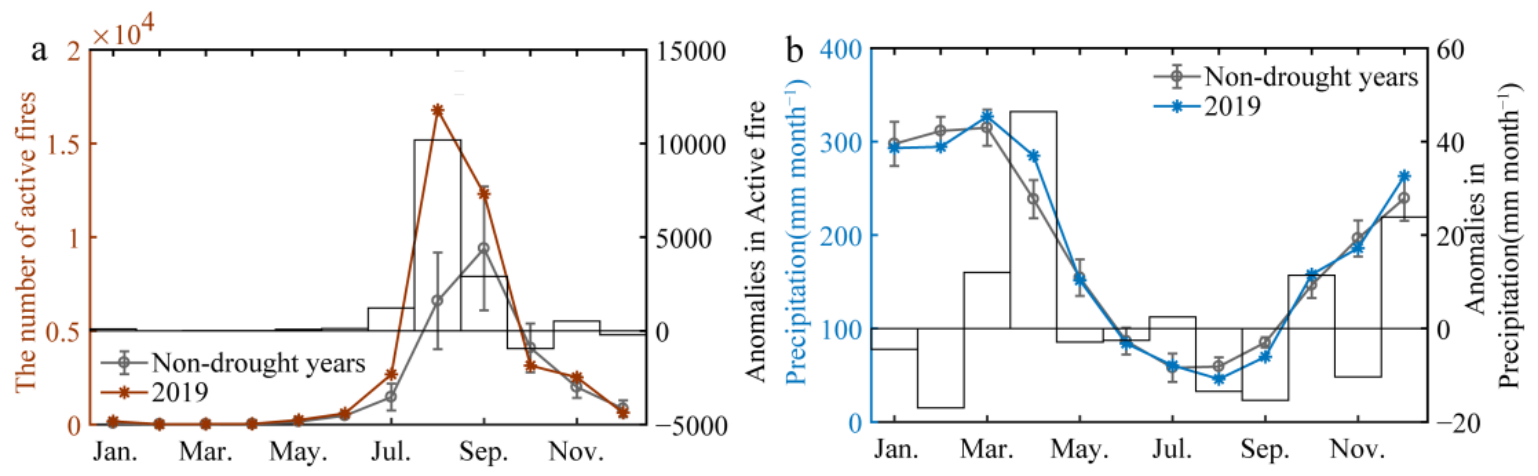

Figure 2. A comparison of monthly averaged (a) active fires and (b) precipitation between 2019 and non-drought years. Colored lines with asterisks show the averages of each month in 2019, whereas gray lines with circles show the averages of each month in the non-drought years with standard deviations indicated by an error bar. The anomalies of each month in 2019 are shown as bar charts with a black line.

Spatially, active fires were mainly located at the forest margins in July 2019 and spread into the forest in August and September (Figure 3a1-a4). In October 2019, the zone with increasing fire occurrences was mainly the northeast of the study area, which was different from other months during the fire season (Figure 3a4 and Figure S3d). Most of the fires occurred over Brazil in 2019 (Figure 3a1-a4). 

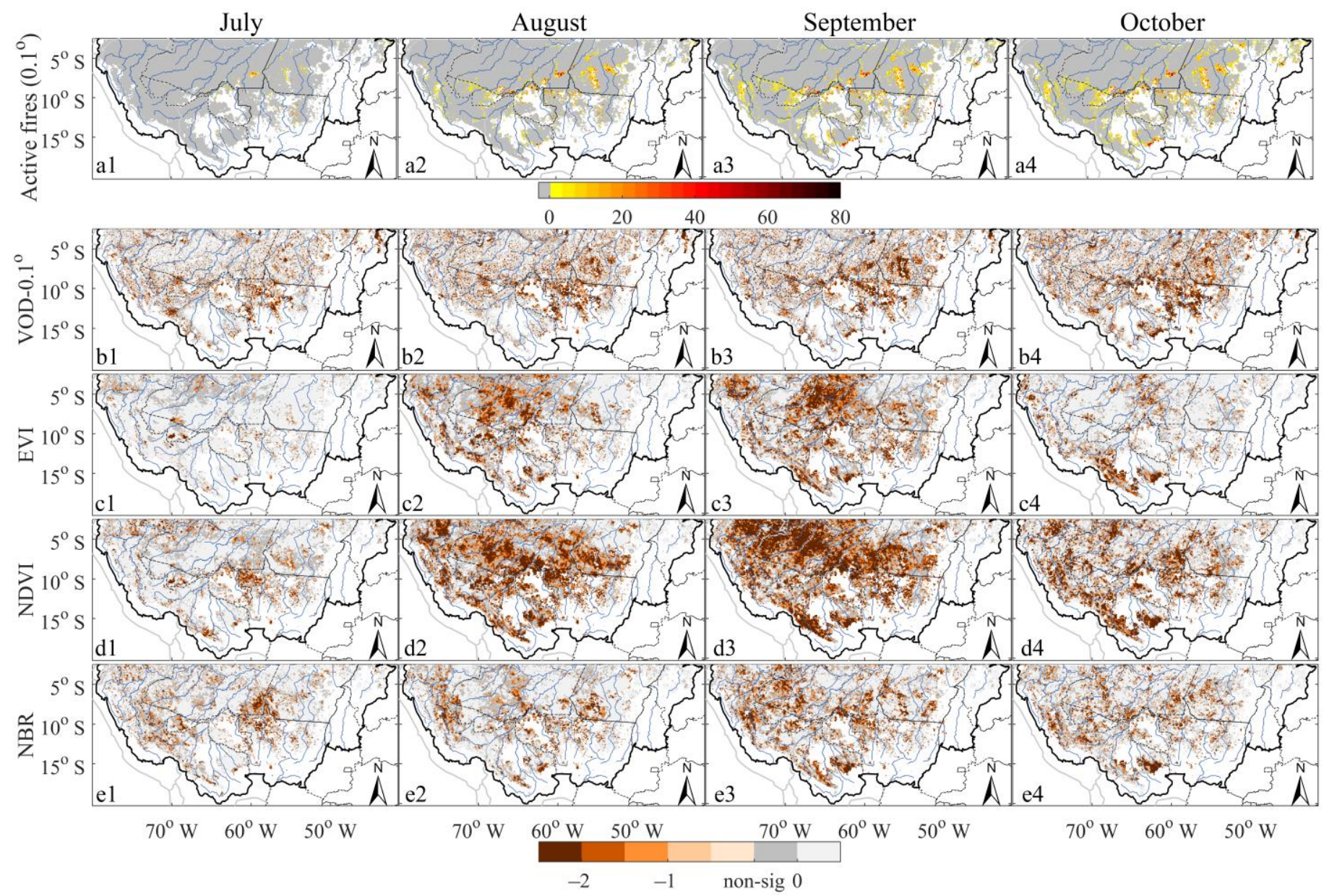

Figure 3. Spatial distribution of cumulative active fires on $0.1^{\circ}$ (a1-a4) grid cells from July to October 2019. Spatial distribution of standardized anomalies for July-October 2019 in (b1-b4) VOD-0.1 ${ }^{\circ}$; (c1-c4) EVI; (d1-d4) NDVI; and (e1-e4) NBR with the $0.1^{\circ}$ spatial resolution.

\subsection{Vegetation Response during the Fire Season}

The spatial distribution between the cumulative active fires and the significant negative anomalies of vegetation metrics at each month were compared by direct observations (Figure 3). It was found that the location with a concentrated distribution of significant negative VOD anomalies coincided with the area with a higher number of active fires over the fire season generally, except in July (Figure 3a1-a4,b1-b4 and Figure S4a1-a4,b1-b4). The comparison of the location of fire pixels and significant vegetation metrics anomalies demonstrated this further (Figure S5). With the decreasing number of active fires in October, significant negative VOD anomalies were reduced (Figure 3b4). However, there was a poor consistency in spatiotemporal distribution between the cumulative active fires and the concentrated distribution of significant negative anomalies in the optical indices (Figure 3). The concentrated distribution of significant negative optical indices anomalies was not only observed in burned areas but also in the unburned areas, which made it hard to discern the area affected by the fire from the spatial distribution of standard anomalies by direct observations. Compared to the spatial distribution of VOD anomalies, there were large-scale significant negative anomalies in the unburned grid cells of the optical indices, especially in the west of the southern Amazon of the NDVI/NBR of September (Figure 3, Figures S5 and S6). From here, a high burned area was chosen to compare the differences in spatiotemporal distribution between VOD standard anomalies at the two resolutions (Figure S7). In some grid cells with few active fires near the edge of unburned pixels, only VOD- $0.1^{\circ}$ could detect the significant canopy changes caused by fire indicated 
by negative anomalies. VOD- $0.1^{\circ}$ showed more detailed information about the canopy changes compared with VOD- $0.25^{\circ}$ in the burned pixels around the center of the severe fire. The correlation of active fires and VOD standard anomalies showed more differences between the results from VOD- $0.1^{\circ}$ and VOD- $0.25^{\circ}$ (Figure S7e1-e4). Within the range of active fires at the $0.1^{\circ}$ resolution, the standard anomalies of VOD- $0.1^{\circ}$ were consistent with VOD- $0.25^{\circ}$ anomalies and showed more abundant information on the canopy changes caused by fire. The VOD- $0.25^{\circ}$ negative anomalies showed a similar magnitude for the increasing number of active fires, except in September.

Besides, the magnitude and spatial coverage of negative VOD anomalies increased with the rising number of active fires from July to September. The negative VOD anomalies in the area with no increased active fires in September (Figure S3) were larger than in August. The area with negative VOD anomalies was larger than that of the fire region (Figure 3b2-b4, Figures S4b2-b4, and S5a2-a4, b2-b4). The mean value of standard anomalies of VOD-0.1 in unburned pixels at different distances from burned pixels clearly showed that the canopy in unburned pixels was influenced by the nearly burned pixels (Figure 4a). The negative VOD anomalies mean that unburned pixels reduced with the increased distance between unburned and burned pixels, which ranged from 0 to $35 \mathrm{~km}$, then stabilized after exceeding $35 \mathrm{~km}$. VOD- $0.1^{\circ}$ showed the effects of fire to the close unburned areas more precisely when compared to VOD- $0.25^{\circ}$ (Figure S8). The NBR showed a similar pattern to that of the VOD, but the distance affected by fire was about $0-10 \mathrm{~km}$. The series of the EVI and the NDVI showed negative anomalies in August-September and kept steady during $10-50 \mathrm{~km}$, then they did not stabilize with the increasing distance (Figure 4c,d). The NDVI in October still showed negative anomalies at any distance.
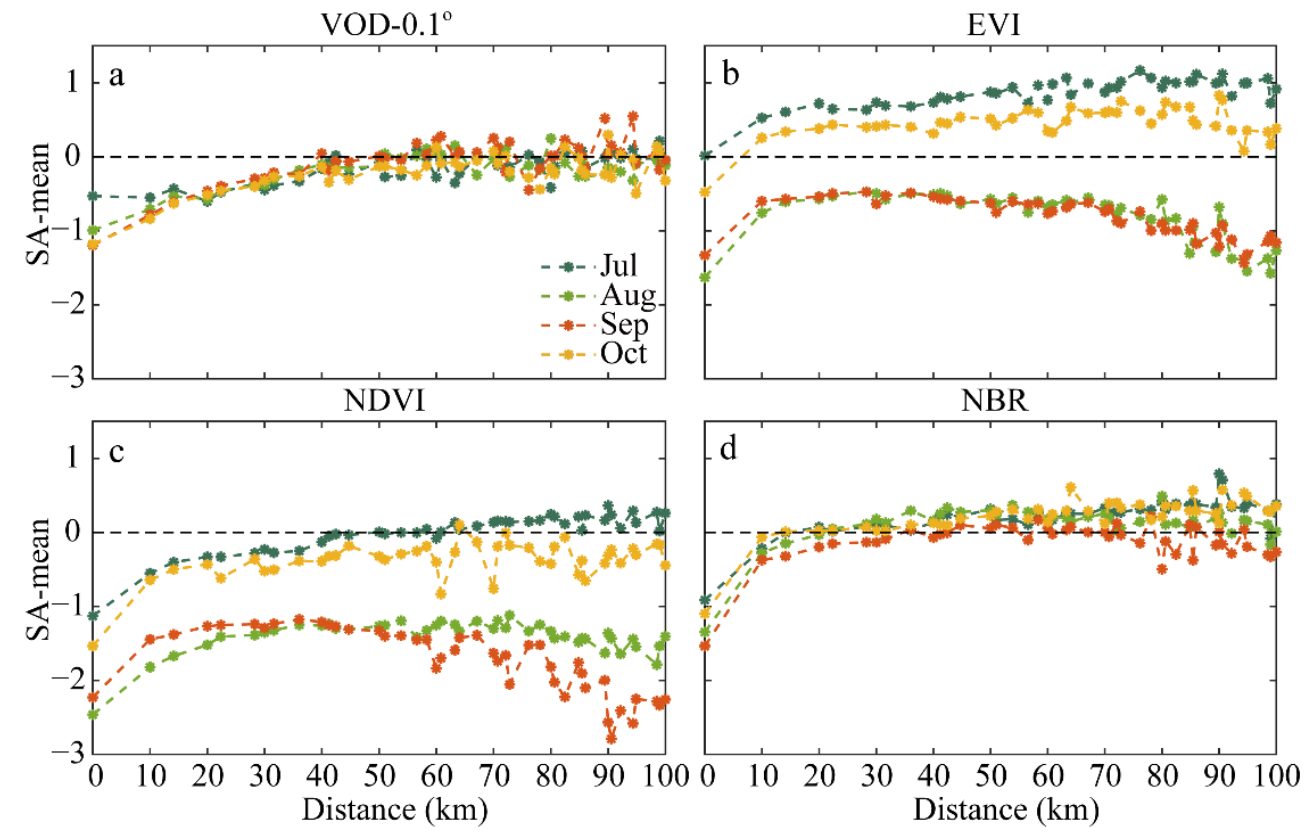

Figure 4. The mean of standard anomalies (SA-mean) of (a) VOD-0.1 ; (b) EVI; (c) NDVI; and (d) NBR in unburned pixels at different distances from burned pixels.

Anomalies from the remotely sensed products in burned pixels were statistically different from those of unburned pixels $(p<0.05)$ and displayed a strong negative skew (Figure 5). In general, from July to September, the percentage of negative anomalies in the burned pixels increased with the rise in fire activity, and the median of anomalies became more negative, whereas the unburned pixels anomalies showed very small changes, except the EVI and the NDVI. Thus, the burned pixel anomalies' negatively skewed distributions gradually moved away from the unburned pixel anomalies distributions from July to September. With the end of the fire season in October, the percentage of negative 
anomalies (i.e., < -2 SD) in burned pixels reduced, causing the burned pixels' anomalies to become more skewed towards unburned pixels, which was consistent with the expected canopy recovery. However, the EVI and NDVI anomalies in burned and unburned pixels both showed a strong negative skew in August and September, moving away from the normal distribution from July-September gradually with a $20-40 \%$ increased percentage of negative anomalies. Although the medians of the EVI and the NDVI anomalies in September were slightly smaller than those of August, the percentage of negative anomalies of the EVI and the NDVI in September were slightly larger than that of August. In October, the EVI and NDVI anomalies in unburned pixels displayed a normal distribution, whereas the anomalies in burned pixels still performed as a negative skew with fewer negative anomalies than in September.

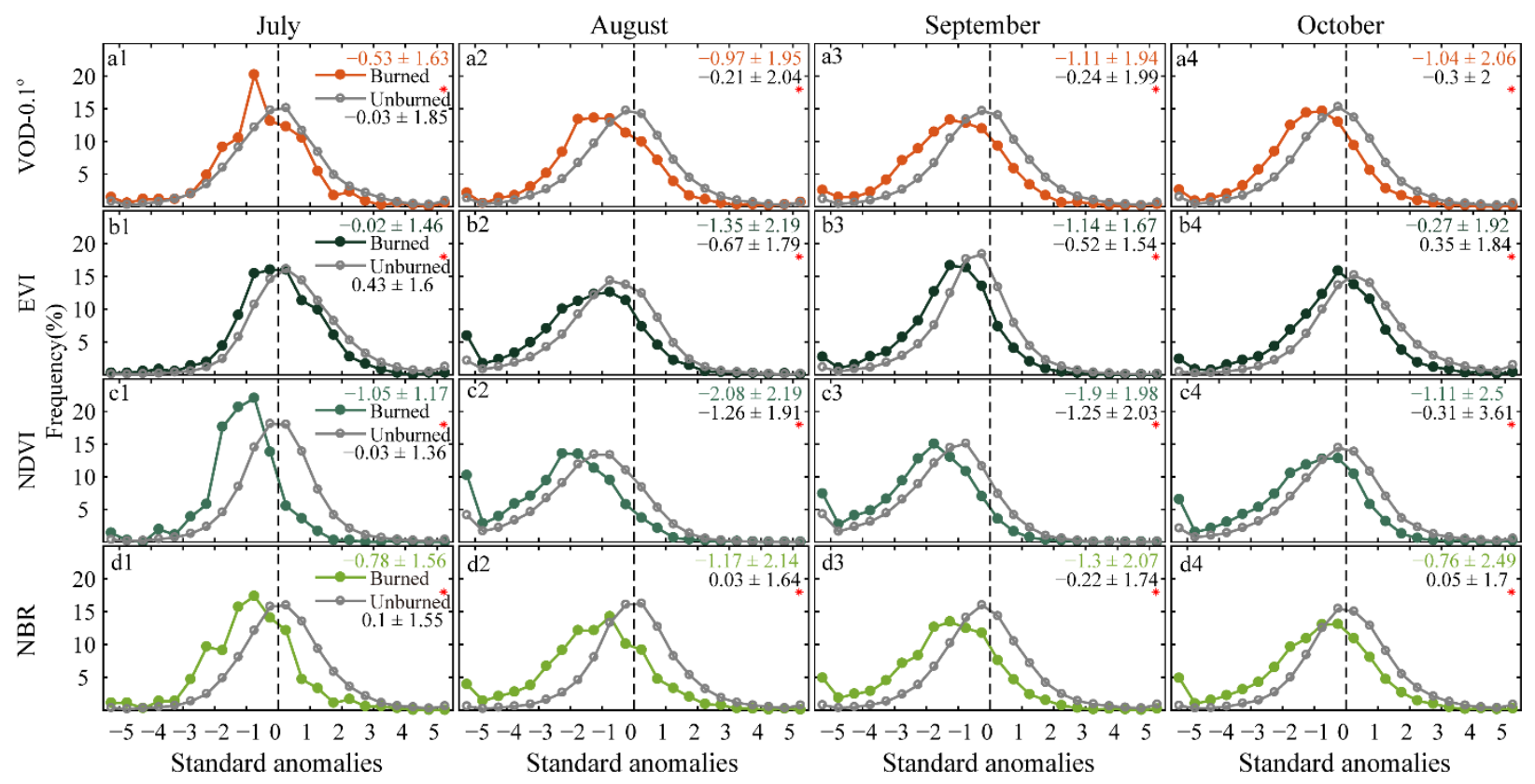

Figure 5. A comparison of standardized anomalies' distribution between burned and unburned pixels in remote sense indices over July-October. Histograms of standardized anomalies from July to October in (a1-a4) VOD-0.1 ${ }^{\circ}$; (b1-b4) EVI; (c1-c4) NDVI; and (d1-d4) NBR. A red asterisk indicates that the anomalies between burned and unburned pixels were significantly different.

Some differences were found among the anomalies of the burned pixel distribution in the VOD, the EVI, the NDVI, and the NBR regarding the percentage of anomalies for different magnitudes (Figure 5). Optical indices showed a higher median of negative anomalies and a higher percentage of negative anomalies in burned pixels over JulySeptember than the VOD, except for the EVI in July (Figure 5). The percentage difference of negative anomalies $(<-1 \mathrm{SD})$ between October and September was greater in optical indices. The declined percentage of negative anomalies in October relative to September was $24 \%, 23 \%$, and $14 \%$ in the EVI, the NDVI and the NBR, respectively, whereas it was $0 \%$ and $1.55 \%$ in VOD- 0.25 (Figure S4c1-c4) and VOD-0.1 respectively. The anomalies distribution in the burned pixels of the VOD products at low and high resolutions also showed some differences. There were $42.5 \%, 49.5 \%$, and $49.5 \%$ of burned pixels with negative VOD- $0.25^{\circ}$ anomalies of more than one standard deviation over August-October (Figure S4(c2-c4)), versus $49.2 \%, 52.5 \%$, and $50.9 \%$ of burned pixels with negative VOD-0.1 ${ }^{\circ}$ anomalies (Figure $5 \mathrm{a} 2-\mathrm{a} 4$ ). The negative VOD- $0.25^{\circ}$ anomalies' distribution changed from September to October (Figure S4c3-c4). The $5.4 \%$ of burned pixels with negative VOD$0.25^{\circ}$ anomalies greater than two standard deviations $(<-2 \mathrm{SD})$ in September decreased in October, and the increasing percentage of negative anomalies between -2 SD and -1 SD led to a similar percentage of negative anomalies $(<-1 \mathrm{SD})$ and median values in September 
and October. However, there were only $3.67 \%$ of burned pixels with negative VOD- $0.1^{\circ}$ anomalies $(<-2 \mathrm{SD})$ decreased in October compared with September.

\subsection{Vegetation Changes Caused by the 2019 Fires}

An overall pattern of fewer negative anomalies at lower levels of active fires for all indices and more negative anomalies at higher levels of active fire was observed (Figure 6). The means of standard anomalies of vegetation metrics were negative at all fire levels, and the mean values increased with the rising fire levels. The pattern was more apparent in August-September and had a significant negative correlation. The Pearson correlation coefficient of optical indices was larger than the VOD. The mean of negative anomalies of optical indices was larger than that of the VOD in all fire levels of August, around 0.1-2.2, and about 0.1-1.7 in most of the fire levels of September ( $>$ four active fires). In July, with low active fires, the anomalies' mean series of VOD and the optical indices at different fire levels were not consistent, and the mean was smaller. Nevertheless, the anomalies' mean series of NDVI/NBR in July was similar to that of August-September. Comparing the means of standard anomalies of vegetation metrics between September and October at different fire levels, we found that the negative anomalies' mean values in lower fire levels (< eight active fires) decreased obviously in October, whereas little or no decrease was observed in higher fire levels. The decline in negative VOD anomalies in October relative to September was less than the optical indices, which was estimated between 0 and 0.1 for the VOD and at least 0.3 for the optical indices. The negative anomalies' decline of VOD-0.1 ${ }^{\circ}$ (Figure 6a4) was less than for VOD- $0.25^{\circ}$ (Figure S4d4). Meanwhile, the mean standard anomalies of the remotely sensed indices at different fire levels based on the monthly cumulative burn area data also showed the same canopy change patterns caused by fire (Figure S9).
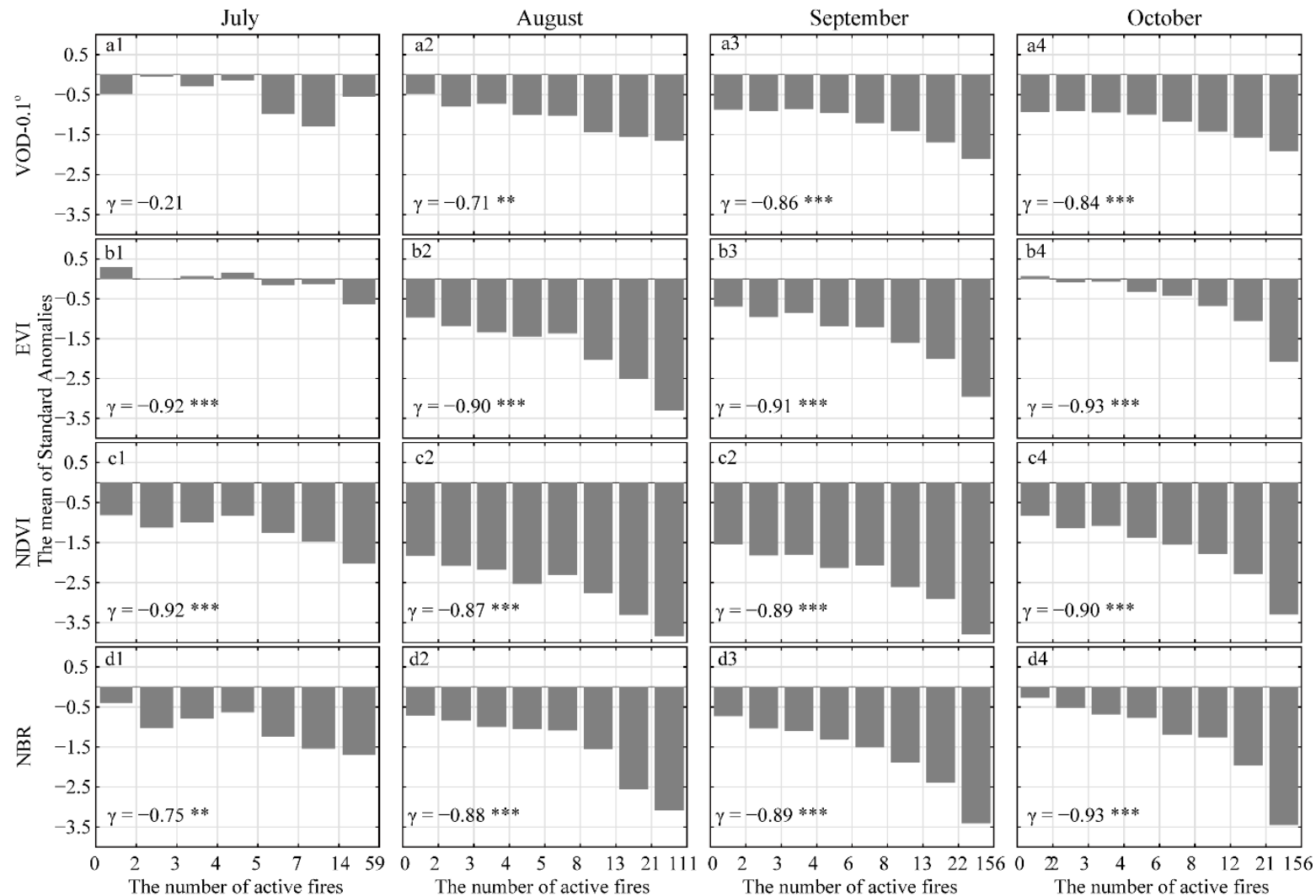

Figure 6. The mean of standard anomalies of (a1-a4) VOD-0.1 ${ }^{\circ}$; (b1-b4) EVI; (c1-c4) NDVI; and (d1-d4) NBR at different fire event levels from July to October. The significant Pearson correlation coefficient $(p<0.1, p<0.05$, and $p<0.01)$ was indicated with ${ }^{*}, * *$, and ${ }^{* * *}$, respectively. 
Regarding the canopy change in the fire season, all the $\Delta(\mathrm{VM})$ standardized anomalies in burned pixels were statistically different from those in unburned pixels $(p<0.05)$ (Figure 7a1-a4). The percentage of negative anomalies of burned pixels was greater in the VOD and the NDVI. The standardized anomalies' averages for all $\Delta(\mathrm{VM})$ were negative at all fire levels (Figure $7 \mathrm{~b} 1-\mathrm{b} 4$ ). In the areas with a small number of active fires, the anomalies' mean was less than -1 SD, which was caused by the decline of negative anomalies in the area with a lower fire level in October according to the above monthly analysis (Figure 6). However, the VOD's, the EVI's, and the NBR's means were larger than -1 SD at the ninth and tenth fire levels, whereas the mean of the NDVI was larger than -1 SD during the seventh to the tenth fire level. The mean of VOD- $0.1^{\circ}$ from the seventh to the tenth fire level was close to or larger than $-1 \mathrm{SD}$, whereas the VOD- $0.25^{\circ}$ average was larger than -1 $\mathrm{SD}$ only at the ninth and tenth fire levels (Figure S10b). The mean of VOD-0.1 at the lower fire levels was larger than that of VOD- $0.25^{\circ}$.

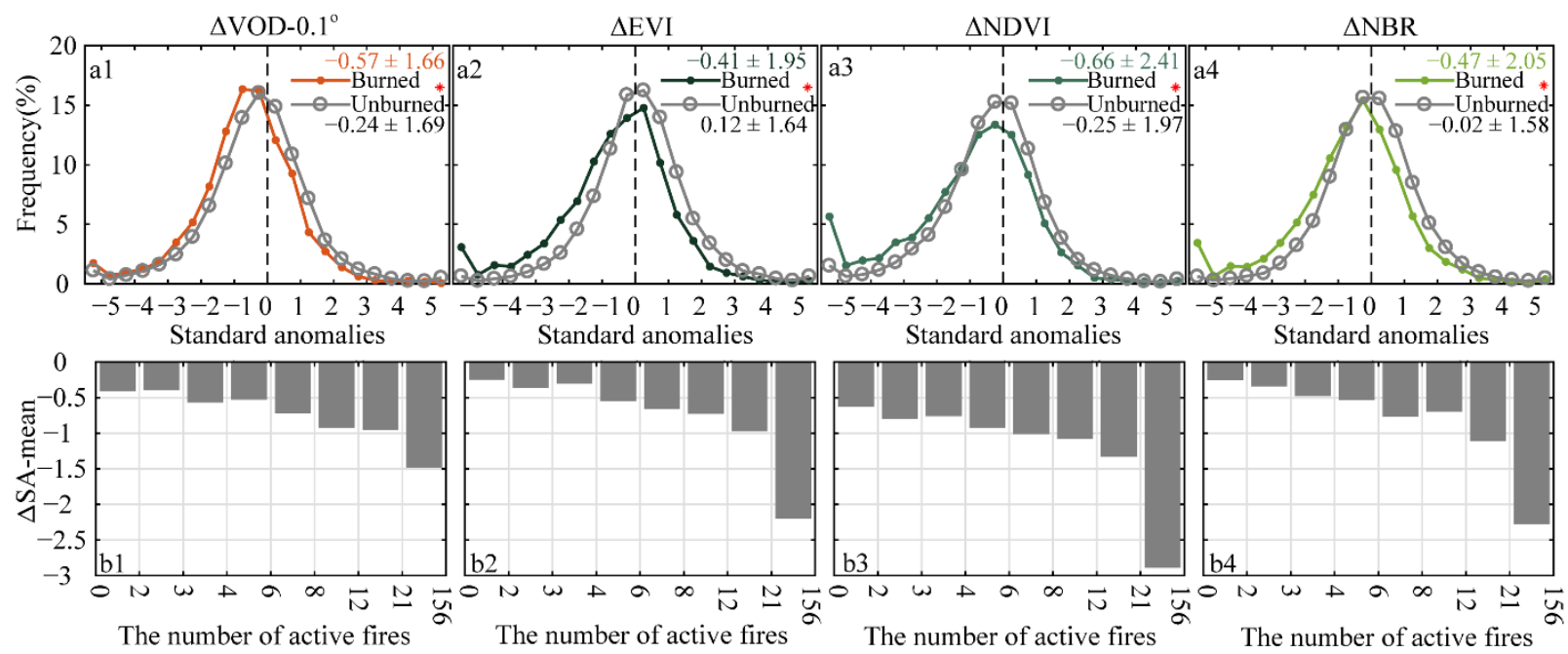

Figure 7. The comparison of $\Delta \mathrm{VM}\left(\Delta \mathrm{VM}=\mathrm{VM}_{\mathrm{Oct}}-\mathrm{VM}_{\mathrm{Jul}}\right)$ standardized anomalies' distribution between burned and unburned areas. Histograms of standardized anomalies in (a1) $\Delta$ VOD-0.1 ${ }^{\circ}$; (a2) $\Delta \mathrm{EVI} ;$ (a3) $\Delta$ NDVI; and (a4) $\Delta$ NBR. A red asterisk indicated that the anomalies between burned and unburned pixels were significantly different. The mean of standard anomalies of (b1) $\triangle$ VOD- $0.21^{\circ}$; (b2) $\triangle \mathrm{EVI}$; (b3) $\triangle \mathrm{NDVI}$; and (b4) $\Delta$ NBR at different fire event levels.

\section{Discussion}

This is the first attempt at VOD data used to characterize tropical forests' canopy dynamics in relation to fire effects. The study was based on the 2019 southern Amazon fire where precipitation in 2019 was similar to that of the non-drought years. There were no extreme hydrometeorological events in 2019 [46,59] supporting the idea that canopy dynamics here observed were driven by fire rather than drought. In this study, the canopy dynamics driven by fires observed by the VOD were found to be similar to optical indices that were usually used to monitor the vegetation changes associated with fire or other disturbance factors. Our findings show that canopy dynamics vary as a function of fire intensity, with increased change with higher fire incidences. This corroborates previous studies [51]. Cochrane and Schulze [60] used field data from the eastern Amazon and estimated the biomass loss in burned forest compared to unburned forest; they found that biomass loss increased as the combustion degree rose, with $80 \%$, $50 \%$, and $10 \%$ losses in heavily, moderately, and lightly burned forest, respectively. In October, the canopy began to recover after fires. There are many factors affecting postfire forest canopy recovery, including pre-fire environment (forest composition, structure, and species ecology), climate, forest fire type (ground, surface, crown), fire intensity, fire severity, and ecotype condition [17]. Fire intensity and fire severity are some of the most important factors influencing the speed of canopy recovery after fire [17,61]. The increased 
fire intensity and fire severity induced the larger loss of biomass and the lower forest resilience. Numata et al. [5] found it was difficult to distinguish the area with low fire intensity and fire severity from intact forest in the early stages of canopy recover, but it was still easy to identify the burn area with higher fire severity in a long period. The canopy recovery indicated from this study was consistent with previous studies. The canopy recovery in the lower fire incidence areas would have started when the fires stopped at the end of the fire season because of rapid canopy regeneration and closure in lightly burned forest $[19,20,62]$. The canopy recovery was not found in higher fire-occurrence areas, likely because of the prolonged effects of fire in the canopy caused by higher fire intensity [63]. The assessment of canopy changes caused by fire here was based on remote sensing indices, which was not completely consistent with the actual forest recovery, particularly the woody part [61]. The canopy changes and recovery indicated from the VOD and the optical indices were different, with higher changes and a faster recovery speed detected by optical indices. The canopy damage indicated by VOD- $0.1^{\circ}$ was larger than that found by VOD- $0.25^{\circ}$, whereas VOD- $0.1^{\circ}$ reflected a slightly lower canopy recovery speed than VOD- $0.25^{\circ}$. This suggests that VOD- $0.1^{\circ}$ was more sensitive to the vegetation change caused by fire than VOD- $0.25^{\circ}$.

The different degree of canopy damage caused by fire and postfire recovery detected by these remote sensing indices may be due to various reasons. The high level of cloud and aerosol contamination in the Amazon may affect the uncertainty of optical indices [64]. The optical indices are obtained by the calculation of the surface reflectance observations that have been atmospherically corrected [48]. The inadequate atmospheric correction of the blue band causes elevated EVI [65], which may lead to the canopy change detected by the EVI being smaller than the NDVI. This also may increase the uncertainty of the EVI and underestimate the vegetation changes caused by fire. In contrast, the high-level aerosol attenuates the band reflection signal used to calculate the NDVI/NBR and obtain the lower value of the NDVI/NBR [65], which may lead to detecting higher canopy changes associated with fire. Although the multi-angle implementation of atmospheric correction algorithm can eliminate the effect of atmospheric contamination and the sunsensor geometry variation more accurately $[52,66,67]$ and can model more realistically the Amazon forest's canopy dynamics [66,68], the uncertainty of MAIAC VI data may still exist in cases of high levels of aerosol contamination caused by fire.

Moreover, the different properties of the forest canopy represented by the corresponding indices may be one reason for the higher canopy changes detected by the optical indices relative to the VOD. The NDVI is sensitive to chlorophyll abundance and photosynthetic biomass. The low reflectivity of the red band, due to the strong red-light absorption of vegetation chlorophyll and the high reflectivity of the NIR band as result of no NIR light absorption in vegetation, achieved the high NDVI [69]. The combination of the NIR and the SWIR absorbed by water to calculate the NBR can find the bare ground information caused by vegetation changes, so that the NBR is low in burned areas [37]. The VOD represents the water content of both photosynthetic and non-photosynthetic biomass, increasing with vegetation density [34]. The slower postfire canopy restoration captured by the VOD also agreed with the expected outcome that the growth of photosynthetic and non-photosynthetic (wood) biomass is slower than the rapid recovery in canopy greenness indicated by the NDVI/NBR [32]. The delayed mortality of large trees ( $\geq 50 \mathrm{~cm} \mathrm{dbh})$ in high fire severity areas demonstrated the properties of wood's response to fire [70]. Moreover, the delayed canopy changes detected by the EVI in July seemed to be relative to the sensitivity of the EVI to structural changes that were mostly detected one month later. Pigments (the NIR band used in the NDVI and the NBR) and water changes (the SWIR and the VOD) were rapidly detected in July when fires started.

Our findings also show that the VOD not only detected the direct effects of fire on the canopy spatially but also seemed to monitor the impact of fire to the adjacent unburned areas. In the Amazon, forest fires are usually associated with deforestation and spread into the adjacent forest, aggravating the forest fragmentation. The forest fragmentation leads to 
the desiccation of surface biomass [4,71,72]. Greater canopy openness induces a significant increase in solar radiation, wind speeds, and vapor pressure deficits, making leaf litter and the aboveground fuels drier [72]. The VOD is sensitive to vegetation water content and could monitor the dryness of the canopy. The magnitude of negative VOD anomalies increased in some places during September, even with no rising active fires compared to August. This was likely to have been caused by the canopy damage in August leading to drier conditions in September. The impact of burned areas to the adjacent unburned areas was similar to a phenomenon known as vegetation breeze, which is a local atmosphere circulation as a result of forest fragmentation where the opening and intact canopy are adjacent. The different physical characteristics between clearings and intact canopy were the main inducement. Lower air pressure is seen in areas with canopy openness because of the increase in solar heating at the surface, and the moist air from the adjacent forest was dragged into the openness canopy, which promoted desiccation of the adjoining forest [4]. In a previous study, it was found that the vegetation breeze can affect the adjacent forest up to $20 \mathrm{~km}$ from clearings in Rondonia [73]. The farthest impact distance of burned areas on adjacent forest was around $30 \mathrm{~km}$ based on the VOD; the negative VOD anomalies in unburned areas decreased with increased distance to the burned area, which suggests that the effect of the burned area is more obvious to the nearby unburned forest.

Different from the VOD, the concentrated distribution of significant negative anomalies of the optical indices was observed in both burned and unburned areas in space, so it cannot intuitively observe the spatial distribution of the effects of fire on vegetation because of the interference of false signals in unburned areas. The results of this study suggests that the VOD can more accurately capture the general spatiotemporal evolution of canopy changes affected by fires, natural conditions, and forest fragmentation associated with fire relative to optical indices, especially where the fire event is unknown and the precipitation anomalies are not very significant. Although the optical indices were contaminated by atmospheric conditions, they still could detect the canopy dynamics caused by fire with the help of fire products. In previous studies that relied on high-resolution optical imagery, a particular challenge was that the time gap between cloud-free image acquisition and fire occurrence possibly led to underestimation of the canopy changes caused by fire $[5,19,20]$. The VOD is less impacted by atmospheric conditions and has a high temporal resolution (twice per day) [35]. Even though the daytime VOD (VOD-day) may not be as reliable as the nighttime VOD (VOD-night), the daytime VOD detected similar canopy dynamics (Figure S11). Furthermore, there was still a difference in performance in July between VOD-night and VOD-day, with a higher percentage of negative VOD-day anomalies in burned and unburned pixels relative to VOD-night.

It should also be noted that some areas with concentrated distributions of significant negative VOD anomalies in July were inconsistent with the corresponding fires' spatial distribution, which may be caused by different factors or a synergy of these factors. The negative VOD anomalies in the Acre state of Brazil with few high-confidence fires (Figure $3 \mathrm{~b} 1$,d1) may have been caused by the low- and nominal-confidence active fires (Figure S12). Fire detection of MCD14ML was obtained from the emission of mid-infrared radiation from fires and a contextual algorithm. MCD14ML may underestimate the fire occurrence as a result of cloud coverage, heavy smoke, a short fire duration between satellite overpasses, the fire being too small or too cool, or the fire being obscured by the canopy. False alarms in small forest clearings have been reduced in MCD14ML. Collection 6 of MCD14ML has improved the fire confidence classification in that some highly questionable fire pixels would not be classified in the nominal-confidence level. MCD14ML can detect fires smaller than 50 ha better than other fire products [74]. The pixels with negative VOD anomalies but no fire occurrence in the Mato Grosso state of Brazil may be caused by the clear-cutting in July 2019 (Figure S13a). There was a large-scale negative VOD-0.25 anomaly in the junction of the Brazilian state of Arce and Peru with bamboo-dominated or bamboo-susceptible forests, which was very likely to be related to the deforestation and fires in 2018 (Figure S13b) or the large-scale die-off of bamboo in bamboo-dominated 
forests in 2019 [68]. Interestingly, VOD-0.1 ${ }^{\circ}$ did not perform a similar large-scale significant negative anomalies distribution in this region but showed more detailed distribution of negative anomalies with significant and non-significant signals.

The forest cover type with a coarse spatial resolution may influence the more realistic identification of canopy dynamic caused by fire in this study. It cannot separate the deforested and fire areas at a $0.1^{\circ}$ or $0.25^{\circ}$ grid cell since the fire is usually associated with deforestation and spreads into the adjacent forest $[44,46]$. The deforestation rate in the Brazilian Amazon has been increased from 2013, especially in 2019 and 2020 [75]. The canopy dynamic associated with fire may be influenced by the vegetation change in deforested areas in burned pixels. However, the impact of deforestation may be minimized by using monthly data for analysis. Although the spatial resolution of the VOD had been enhanced to $0.1^{\circ}$ and the VOD- $0.1^{\circ}$ can obtain more detailed information than VOD-25 is still not enough to meet the higher precision requirements. After all, the forest burned area accounts for just a part of a $0.1^{\circ}$ grid cell.

Although we demonstrated that the VOD is promising in characterizing the vegetation changes during the 2019 dry season, the VOD has its own uncertainties due to the inherent characteristics of the satellite and retrieval algorithm. The VOD was retrieved from the AMSR2 instrument onboard the GCOM-W1 polar-orbiting satellite based on the LPRM. There are several assumptions in the LPRM, leading to the uncertainties of the VOD [76]. For example, the equal assumption of canopy surface temperature and soil surface temperature leads to the higher uncertainties of VOD-day because of the higher temperature gradients in the daytime. VOD-night is more reliable than VOD-day, but the descending orbit overpasses tropical regions about once every two days. VOD-night would miss some canopy change in fast-changing events, such as a fire, if it were used alone to identify the vegetation change. Besides, the surface open water also influences the retrieved VOD, which affects microwave reflection of the ground and causes the underestimation of the VOD $[25,77]$.

Overall, the results of this study prove that the VOD is very useful for monitoring the canopy dynamics caused by fire or postfire recovery and provides more comprehensive information over time relative to the optical indices. The spatial results of the VOD can also provide general indications for postfire management. The VOD and the optical indices are two types of radiometric parameter products with different concepts. Their response to climate conditions and fire do not necessarily consist in a similar pattern [32-34], which implies that the combination of both products can provide a better understanding of vegetation dynamics at different conditions and scale. Moreover, the uncertainties and restrictions in both products also stimulate the combination of multiple radiometric parameter products for vegetation studies in the future. The more comprehensive canopy dynamic description associated with fire is beneficial for the improving of fire-emission estimates and vegetation models too. The importance of carbon emissions in increasing tropical wildfires has been recognized in recent years but is still not recorded in most national or global carbon budget systems [6,78]. The Global Fire Emission Database (GFED) may underestimate carbon emissions from understory fires because of the dependence on burned area products in the estimation process [79]. The emission estimates in most databases are temporal, focusing on immediate emissions from a fire [79]. Silva et al. [80] investigated the long-term consequences of wildfires based on a 30-year study in the Brazilian Amazon and revealed that the net annual emissions peak four years after a wildfire, focusing on $\mathrm{CO}_{2}$ fluxes from the growth and decomposition of woody components. The synergy of the VOD (biomass estimate) and the optical indices (photosynthetic) has the potential to be an effective way of improving the estimation of carbon emissions or stock recovery in the future [32]. At present, the application of the VOD in monitoring canopy dynamics affected by various disturbance factors is still low relative to the use of optical indices, which needs to be further expanded. Although the VOD has been proved to provide complementary information on vegetation change for the optical indices, further 
estimations with field data are also needed to deeply explore the potential advantages of the VOD.

\section{Conclusions}

This study demonstrated the potential of a passive microwave-based vegetation optical depth (VOD) to detect the vegetation change patterns caused by fire over southern Amazonian forest regions with high biomass where fire activity occurs in July-October every year. In the absence of extreme hydrometeorological events, the VOD can reflect the spatiotemporal distribution of fire-driven canopy changes. The VOD with a higher spatial resolution can provide more detailed information on canopy changes. The optical indices cannot spatially distinguish between canopy changes affected by fire from unburned areas because of errors in the canopy change information in unburned areas that are likely due to the effect of atmospheric conditions. The temporal pattern of canopy changes indicated by the VOD and the optical indices was similar when looking only at grid cells with fire activities. The magnitude of canopy damage increased with the rising fire occurrences from July to September. In October, with fires decreasing or stopping, the canopy showed signs of recovery in areas with fewer fires, while canopy restoration in severe fire areas had not yet begun. The lower magnitude of canopy damage and recovery detected by the VOD relative to optical indices was due to the physical meaning of the VOD, which is sensitive to changes in non-photosynthetic (woody) and photosynthetic (foliar) components of vegetation, whereas optical indices are more sensitive to canopy greenness. Because of the different physical meaning, the combination of the VOD and the optical indices can provide a more comprehensive real-time information on the vegetation changes caused by fires at various fire types, fire severity, and regional scales, which should be applied widely in the future.

Supplementary Materials: The following are available online at https://www.mdpi.com/article/ 10.3390/rs13122238/s1. Figure S1: Spatial distribution of land cover type in Amazon with $0.25^{\circ}$ spatial resolution in 2018, Figure S2: The cumulative distribution function (CDF) of cumulative active fires from July to October, Figure S3: Spatial distribution of active fires on $0.1^{\circ}$ grid cells from July to October 2019, Figure S4: Spatial distribution of cumulative active fires on $0.1^{\circ}$ (a1-a4) grid cells from July to October 2019. Spatial distribution of standardized anomalies in (b1-b4) VOD- $0.25^{\circ}$ from July to October 2019. Histograms of standardized anomalies from July to October in (c1-c4) VOD-0.25. Red asterisks indicated that the anomalies between burned and unburned pixels were significantly different. The mean standard anomalies of (d1-d4) VOD- $0.25^{\circ}$ at different fire situation levels from July to October 2019. Significant Pearson correlation coefficient $(p<0.1, p<0.05$ and $p<0.01$ ) was indicated with ***, and ${ }^{* *}$, respectively, Figure S5: A comparison of the locations of burned pixels and significant (a1-a4) VOD-0.25 , (b1-b4) VOD-0.1 ${ }^{\circ}$, (c1-c4) EVI, (d1-d4) NDVI, (e1-e4) NBR anomalies pixels from July to October 2019, Figure S6: The absolute value difference of significant negative anomalies between optical indices and VOD-0.1 ${ }^{\circ}$ in unburned pixels from July to October 2019, Figure S7: A comparison of standard anomalies between fire data and VOD at different resolutions in the higher fire occurrence areas $\left(5^{\circ}-9^{\circ} \mathrm{S}, 52^{\circ}-62^{\circ} \mathrm{W}\right)$ from July to October 2019. (a1-a4) and (d1-d4) was the spatial distribution of cumulative active fires with high-level confidence on $0.25^{\circ}$ and $0.1^{\circ}$ grid cells. (b1-b4) and (c1-c4) was the spatial distribution of standardized anomalies in VOD at low $\left(0.25^{\circ}\right)$ and high resolution $\left(0.1^{\circ}\right)$. The scatter plots of standard anomalies varied with active fires (e1-e4), Figure S8: The mean of standard anomalies (SA-mean) of VOD- $0.25^{\circ}$ in unburned pixels at different distances from burned pixels, Figure S9: The mean standard anomalies of (a1-a4) VOD-0.25 , (b1-b4) VOD-0.1 ${ }^{\circ}$, (c1-c4) EVI, (d1-d4) NDVI, and (e1-e4) NBR at different burn area levels from July to October 2019, Figure S10: The comparison of $\Delta \mathrm{VM}\left(\Delta \mathrm{VM}=\mathrm{VM}_{\mathrm{Oct}}-\mathrm{VM}_{\mathrm{Jul}}\right)$ standardized anomalies' distribution between burned and unburned areas. Histograms of standardized anomalies in $\triangle \mathrm{VOD}-0.25^{\circ}$ (a). A red asterisk indicated that the anomalies between burned and unburned pixels were significantly different. The mean of standard anomalies of $\Delta V O D-0.25^{\circ}$ (b) at different fire event levels, Figure S11: Spatial distribution of standardized anomalies in VOD-0.1 ${ }^{\circ}$ based on daytime passive microwave observation (named VOD-0.1 $1^{\circ}$ A here, a1-a4) from July to October 2019. Histograms of standardized anomalies from July to October in VOD-0.1 $1^{\circ}-\mathrm{A}$ (b1-b4). Red asterisks indicated that the anomalies between burned and unburned pixels were significantly different. The 
mean standard anomalies of VOD- $0.1^{\circ}-\mathrm{A}(\mathrm{c} 1-\mathrm{c} 4)$ at different fire situation levels from July to October 2019, Figure S12: Spatial distribution of cumulative active fires with all confidence levels on $0.1^{\circ}$ grid cells from July to October 2019, Figure S13: A comparison of the locations of burned pixels and deforested pixel in (a) July 2019 and (b) July 2018. F\&D referred to burned pixels with deforested. F referred to burned pixels with no deforested. D referred to deforested pixel with no fire.

Author Contributions: Conceptualization, H.Z. and Y.L.; methodology, H.Z. and Y.L.; writingoriginal draft preparation, H.Z.; writing—review and editing, H.Z., Y.L., D.F.T.H., and R.D.; supervision, Y.L. All authors have read and agreed to the published version of the manuscript.

Funding: This research was funded by a Nanjing University of Information Science and Technology (NUIST) startup grant (2243141701020). R.D. was supported by Sao Paulo Research Foundation (FAPESP) grant 2019/21662-8.

Acknowledgments: In this study, multi-source data were obtained from different data centers. The authors thank NASA and the Clouds and the Earth's Radiant Energy System for making their data freely available. The authors are grateful to the anonymous reviewers and editors for their constructive comments and suggestions.

Conflicts of Interest: The authors declare no conflict of interest.

\section{References}

1. Malhi, Y.; Roberts, J.T.; Betts, R.A.; Killeen, T.J.; Li, W.; Nobre, C.A. Climate Change, Deforestation, and the Fate of the Amazon. Science 2008, 319, 169-172. [CrossRef] [PubMed]

2. Baker, T.R.; Phillips, O.; Malhi, Y.; Almeida, S.; Arroyo, L.; Di Fiore, A.; Erwin, T.; Higuchi, N.; Killeen, T.J.; Laurance, S.G.; et al. Increasing biomass in Amazonian forest plots. Philos. Trans. R. Soc. B Biol. Sci. 2004, 359, 353-365. [CrossRef] [PubMed]

3. Aragão, L.E.O.C.; Poulter, B.; Barlow, J.B.; Anderson, L.O.; Malhi, Y.; Saatchi, S.; Phillips, O.; Gloor, E. Environmental change and the carbon balance of Amazonian forests. Biol. Rev. 2014, 89, 913-931. [CrossRef]

4. Cochrane, M.A.; Laurance, W.F. Synergisms among Fire, Land Use, and Climate Change in the Amazon. Ambio 2008, 37, 522-527. [CrossRef] [PubMed]

5. Numata, I.; Cochrane, M.A.; Galvão, L.S. Analyzing the Impacts of Frequency and Severity of Forest Fire on the Recovery of Disturbed Forest using Landsat Time Series and EO-1 Hyperion in the Southern Brazilian Amazon. Earth Interact. 2011, 15, 1-17. [CrossRef]

6. $\quad$ Aragão, L.E.O.C.; Anderson, L.O.; Fonseca, M.; Rosan, T.M.; Vedovato, L.B.; Wagner, F.H.; Silva, C.V.J.; Junior, C.H.L.S.; Arai, E.; Aguiar, A.P.; et al. 21st Century drought-related fires counteract the decline of Amazon deforestation carbon emissions. Nat. Commun. 2018, 9, 1-12. [CrossRef]

7. Szpakowski, D.M.; Jensen, J.L.R. A Review of the Applications of Remote Sensing in Fire Ecology. Remote Sens. 2019, 11, 2638. [CrossRef]

8. Anderson, L.O.; Aragão, L.E.O.C.; Gloor, M.; Arai, E.; Adami, M.; Saatchi, S.S.; Malhi, Y.; Shimabukuro, Y.E.; Barlow, J.; Berenguer, E.; et al. Disentangling the contribution of multiple land covers to fire-mediated carbon emissions in Amazonia during the 2010 drought. Glob. Biogeochem. Cycles 2015, 29, 1739-1753. [CrossRef]

9. Junior, C.H.L.S.; Anderson, L.O.; Silva, A.L.; Almeida, C.T.; Dalagnol, R.; Pletsch, M.A.J.S.; Penha, T.V.; Paloschi, R.; Aragão, L.E.O.C. Fire Responses to the 2010 and 2015/2016 Amazonian Droughts. Front. Earth Sci. 2019, 7, 97. [CrossRef]

10. Anderson, L.O.; Neto, G.R.; Cunha, A.P.; Fonseca, M.G.; De Moura, Y.M.; Dalagnol, R.; Wagner, F.H.; Aragão, L.E.O.E.C.D. Vulnerability of Amazonian forests to repeated droughts. Philos. Trans. R. Soc. B Biol. Sci. 2018, 373, 20170411. [CrossRef]

11. Cox, P.; Betts, R.A.; Collins, M.; Harris, P.P.; Huntingford, C.; Jones, C.D. Amazonian forest dieback under climate-carbon cycle projections for the 21st century. Theor. Appl. Clim. 2004, 78, 137-156. [CrossRef]

12. Espinoza, J.C.; Segura, H.; Ronchail, J.; Drapeau, G.; Gutierrez-Cori, O. Evolution of wet-day and dry-day frequency in the western A mazon basin: Relationship with atmospheric circulation and impacts on vegetation. Water Resour. Res. 2015, 52, 8546-8560. [CrossRef]

13. Marengo, J.A.; Tomasella, J.; Soares, W.R.; Alves, L.M.; Nobre, C.A. Extreme climatic events in the Amazon basin. Theor. Appl. Clim. 2012, 107, 73-85. [CrossRef]

14. Lewis, S.L.; Brando, P.; Phillips, O.; van der Heijden, G.; Nepstad, D. The 2010 Amazon Drought. Science 2011, 331, 554. [CrossRef]

15. Aragão, L.E.O.C.; Shimabukuro, Y.E. The Incidence of Fire in Amazonian Forests with Implications for REDD. Science 2010, 328, 1275-1278. [CrossRef]

16. Cochrane, M.A.; Barber, C.P. Climate change, human land use and future fires in the Amazon. Glob. Chang. Biol. 2009, 15, 601-612. [CrossRef]

17. Chu, T.; Guo, X. Remote Sensing Techniques in Monitoring Post-Fire Effects and Patterns of Forest Recovery in Boreal Forest Regions: A Review. Remote Sens. 2013, 6, 470-520. [CrossRef] 
18. Morton, D.C.; DeFries, R.S.; Nagol, J.; Souza, C.M.; Kasischke, E.S.; Hurtt, G.C.; Dubayah, R. Mapping canopy damage from understory fires in Amazon forests using annual time series of Landsat and MODIS data. Remote Sens. Environ. 2011, 115, 1706-1720. [CrossRef]

19. Souza, C.M.; Roberts, D.A.; Cochrane, M.A. Combining spectral and spatial information to map canopy damage from selective logging and forest fires. Remote Sens. Environ. 2005, 98, 329-343. [CrossRef]

20. Souza, C.M.; Roberts, D.A.; Monteiro, A. Multitemporal Analysis of Degraded Forests in the Southern Brazilian Amazon. Earth Interact. 2005, 9, 1-25. [CrossRef]

21. Stone, T.A.; Lefebvre, P. Using multi-temporal satellite data to evaluate selective logging in Para, Brazil. Int. J. Remote Sens. 1998, 19, 2517-2526. [CrossRef]

22. Da Silva, S.S.; Fearnside, P.M.; Graça, P.M.L.D.A.; Brown, I.F.; Alencar, A.; de Melo, A.W.F. Dynamics of forest fires in the southwestern Amazon. For. Ecol. Manag. 2018, 424, 312-322. [CrossRef]

23. Lambin, E.F. Monitoring forest degradation in tropical regions by remote sensing: Some methodological issues. Glob. Ecol. Biogeogr. 1999, 8, 191-198. [CrossRef]

24. Saatchi, S.; Asefi-Najafabady, S.; Malhi, Y.; Aragão, L.E.O.C.; Anderson, L.; Myneni, R.; Nemani, R. Persistent effects of a severe drought on Amazonian forest canopy. Proc. Natl. Acad. Sci. USA 2013, 110, 565-570. [CrossRef] [PubMed]

25. Liu, Y.Y.; Van Dijk, A.I.J.M.; McCabe, M.; Evans, J.; De Jeu, R.A.M. Global vegetation biomass change (1988-2008) and attribution to environmental and human drivers. Glob. Ecol. Biogeogr. 2012, 22, 692-705. [CrossRef]

26. Reiche, J.; Verhoeven, R.; Verbesselt, J.; Hamunyela, E.; Wielaard, N.; Herold, M. Characterizing Tropical Forest Cover Loss Using Dense Sentinel-1 Data and Active Fire Alerts. Remote Sens. 2018, 10, 777. [CrossRef]

27. Bruggisser, M.; Dorigo, W.; Dostálová, A.; Hollaus, M.; Navacchi, C.; Schlaffer, S.; Pfeifer, N. Potential of Sentinel-1 C-Band Time Series to Derive Structural Parameters of Temperate Deciduous Forests. Remote Sens. 2021, 13, 798. [CrossRef]

28. Pfeil, I.; Wagner, W.; Forkel, M.; Dorigo, W.; Vreugdenhil, M. Does ASCAT observe the spring reactivation in temperate deciduous broadleaf forests? Remote Sens. Environ. 2020, 250, 112042. [CrossRef]

29. Vreugdenhil, M.; Navacchi, C.; Bauer-Marschallinger, B.; Hahn, S.; Steele-Dunne, S.; Pfeil, I.; Dorigo, W.; Wagner, W. Sentinel-1 Cross Ratio and Vegetation Optical Depth: A Comparison over Europe. Remote Sens. 2020, 12, 3404. [CrossRef]

30. Moesinger, L.; Dorigo, W.; De Jeu, R.; Van Der Schalie, R.; Scanlon, T.; Teubner, I.; Forkel, M. The global long-term microwave Vegetation Optical Depth Climate Archive (VODCA). Earth Syst. Sci. Data 2020, 12, 177-196. [CrossRef]

31. Zhou, L.; Tian, Y.; Myneni, R.; Ciais, P.; Saatchi, S.; Liu, Y.Y.; Piao, S.; Chen, H.; Vermote, E.F.; Song, C.; et al. Widespread decline of Congo rainforest greenness in the past decade. Nat. Cell Biol. 2014, 509, 86-90. [CrossRef]

32. Jones, M.O.; Kimball, J.S.; Jones, L.A. Satellite microwave detection of boreal forest recovery from the extreme 2004 wildfires in Alaska and Canada. Glob. Chang. Biol. 2013, 19, 3111-3122. [CrossRef]

33. Jones, M.O.; Jones, L.A.; Kimball, J.S.; McDonald, K.C. Satellite passive microwave remote sensing for monitoring global land surface phenology. Remote Sens. Environ. 2011, 115, 1102-1114. [CrossRef]

34. Liu, Y.Y.; De Jeu, R.A.M.; McCabe, M.; Evans, J.; Van Dijk, A.I.J.M. Global long-term passive microwave satellite-based retrievals of vegetation optical depth. Geophys. Res. Lett. 2011, 38. [CrossRef]

35. Liu, Y.Y.; van Dijk, A.I.; Miralles, D.G.; McCabe, M.; Evans, J.; de Jeu, R.A.; Gentine, P.; Huete, A.; Parinussa, R.M.; Wang, L.; et al. Enhanced canopy growth precedes senescence in 2005 and 2010 Amazonian droughts. Remote Sens. Environ. 2018, 211, 26-37. [CrossRef]

36. Tian, F.; Brandt, M.; Liu, Y.Y.; Verger, A.; Tagesson, T.; Diouf, A.A.; Rasmussen, K.; Mbow, C.; Wang, Y.; Fensholt, R. Remote sensing of vegetation dynamics in drylands: Evaluating vegetation optical depth (VOD) using AVHRR NDVI and in situ green biomass data over West African Sahel. Remote Sens. Environ. 2016, 177, 265-276. [CrossRef]

37. Chen, X.; Liu, Y.Y.; Evans, J.; Parinussa, R.M.; Van Dijk, A.I.J.M.; Yebra, M. Estimating fire severity and carbon emissions over Australian tropical savannahs based on passive microwave satellite observations. Int. J. Remote Sens. 2018, 39, 6479-6498. [CrossRef]

38. Van Marle, M.J.E.; Van Der Werf, G.R.; De Jeu, R.A.M.; Liu, Y.Y. Annual South American forest loss estimates based on passive microwave remote sensing (1990-2010). Biogeosciences 2016, 13, 609-624. [CrossRef]

39. Liu, Y.Y.; Van Dijk, A.I.J.M.; De Jeu, R.A.M.; Canadell, J.; McCabe, M.; Evans, J.; Wang, G. Recent reversal in loss of global terrestrial biomass. Nat. Clim. Chang. 2015, 5, 470-474. [CrossRef]

40. Fan, L.; Wigneron, J.-P.; Ciais, P.; Chave, J.; Brandt, M.; Fensholt, R.; Saatchi, S.S.; Bastos, A.; Al-Yaari, A.; Hufkens, K.; et al. Satellite-observed pantropical carbon dynamics. Nat. Plants 2019, 5, 944-951. [CrossRef]

41. Wigneron, J.-P.; Jackson, T.; O’Neill, P.; De Lannoy, G.; de Rosnay, P.; Walker, J.; Ferrazzoli, P.; Mironov, V.; Bircher, S.; Grant, J.; et al. Modelling the passive microwave signature from land surfaces: A review of recent results and application to the L-band SMOS \& SMAP soil moisture retrieval algorithms. Remote Sens. Environ. 2017, 192, 238-262. [CrossRef]

42. Tian, F.; Brandt, M.; Liu, Y.Y.; Rasmussen, K.; Fensholt, R. Mapping gains and losses in woody vegetation across global tropical drylands. Glob. Chang. Biol. 2016, 23, 1748-1760. [CrossRef]

43. Gevaert, A.; Parinussa, R.; Renzullo, L.; van Dijk, A.; de Jeu, R. Spatio-temporal evaluation of resolution enhancement for passive microwave soil moisture and vegetation optical depth. Int. J. Appl. Earth Obs. Geoinf. 2016, 45, 235-244. [CrossRef] 
44. Silveira, M.V.F.; Petri, C.A.; Broggio, I.S.; Chagas, G.O.; Macul, M.S.; Leite, C.C.S.S.; Ferrari, E.M.M.; Amim, C.G.V.; Freitas, A.L.R.; Motta, A.Z.V.; et al. Drivers of Fire Anomalies in the Brazilian Amazon: Lessons Learned from the 2019 Fire Crisis. Land 2020, 9 , 516. [CrossRef]

45. Lizundia-Loiola, J.; Pettinari, M.L.; Chuvieco, E. Temporal Anomalies in Burned Area Trends: Satellite Estimations of the Amazonian 2019 Fire Crisis. Remote Sens. 2020, 12, 151. [CrossRef]

46. Barlow, J.; Berenguer, E.; Carmenta, R.; França, F. Clarifying Amazonia's burning crisis. Glob. Chang. Biol. 2019, 26, 319-321. [CrossRef] [PubMed]

47. Saleska, S.R.; Didan, K.; Huete, A.; Da Rocha, H.R. Amazon Forests Green-Up During 2005 Drought. Science 2007, $318,612$. [CrossRef] [PubMed]

48. Owe, M.; De Jeu, R.; Walker, J. A methodology for surface soil moisture and vegetation optical depth retrieval using the microwave polarization difference index. IEEE Trans. Geosci. Remote Sens. 2001, 39, 1643-1654. [CrossRef]

49. Meesters, A.; De Jeu, R.; Owe, M. Analytical Derivation of the Vegetation Optical Depth From the Microwave Polarization Difference Index. IEEE Geosci. Remote Sens. Lett. 2005, 2, 121-123. [CrossRef]

50. Owe, M.; De Jeu, R.; Holmes, T. Multisensor historical climatology of satellite-derived global land surface moisture. J. Geophys. Res. Space Phys. 2008, 113. [CrossRef]

51. Dalagnol, R.W.; Hubert, F.; Galvão, L.S.; Aragão, L.E.O.eC. The MANVI Product: MODIS (MAIAC) Nadir-Solar Adjusted Vegetation Indices (EVI and NDVI) for South America; (Version v1); Zenodo: Sao Paulo, Brazil, 2019. [CrossRef]

52. Lyapustin, A.; Martonchik, J.; Wang, Y.; Laszlo, I.; Korkin, S. Multiangle implementation of atmospheric correction (MAIAC): 1. Radiative transfer basis and look-up tables. J. Geophys. Res. Space Phys. 2011, 116. [CrossRef]

53. Santana, N.C.; Júnior, O.A.D.C.; Gomes, R.A.T.; Guimarães, R.F. Burned-Area Detection in Amazonian Environments Using Standardized Time Series Per Pixel in MODIS Data. Remote Sens. 2018, 10, 1904. [CrossRef]

54. Kamel, D.; Munoz, A.B.; Ramon, S.; Huete, A. MODIS Vegetation Index User's Guide; Vegetation Index and Phenology Lab of The University of Arizona, The University of Arizona: Tucson, AZ, USA, 2015.

55. Giglio, L.; Boschetti, L.; Roy, D.P.; Humber, M.L.; Justice, C.O. The Collection 6 MODIS burned area mapping algorithm and product. Remote Sens. Environ. 2018, 217, 72-85. [CrossRef] [PubMed]

56. Huffman, G.J.; Stocker, E.F.; Bolvin, D.T.; Nelkin, E.J.; Tan, J. GPM IMERG Final Precipitation L3 1 Month 0.1 Degree $x 0.1$ Degree V06; Goddard Earth Sciences Data and Information Services Center (GES DISC): Greenbelt, MD, USA, 2019. [CrossRef]

57. Gibbons, J.D.; Chakraborti, S. Nonparametric Statistical Inference, 5th ed.; Taylor \& Francis Ltd.: Boca Raton, FL, USA, 2011.

58. Hollander, M.; Wolfe, D.A. Nonparametric Statistical Methods; John Wiley \& Sons, Inc.: Hoboken, NJ, USA, 1999.

59. Yao, J.; Zhai, H.R.; Tang, X.M.; Gao, X.M.; Yang, X.D. Amazon Fire Monitoring and Analysis Based on Multi-source Remote Sensing Data. In IOP Conference Series: Earth and Environmental Science; IOP Publishing: Bristol, UK, 2020 ; Volume 474.

60. Cochrane, M.; Schulze, M.D. Forest fires in the Brazilian amazon. Conserv. Biol. 1998, 12, 948-950. [CrossRef]

61. Martins, F.D.S.R.V.; Xaud, H.A.M.; Dos Santos, J.R.; Galvão, L.S. Effects of fire on above-ground forest biomass in the northern Brazilian Amazon. J. Trop. Ecol. 2012, 28, 591-601. [CrossRef]

62. Da Silva, S.S.; Oliveira, I.; Morello, T.F.; Anderson, L.O.; Karlokoski, A.; Brando, P.M.; de Melo, A.W.F.; da Costa, J.G.; de Souza, F.S.C.; da Silva, I.S.; et al. Burning in southwestern Brazilian Amazonia, 2016-2019. J. Environ. Manag. 2021, $286,112189$. [CrossRef] [PubMed]

63. Alencar, A.; Asner, G.P.; Knapp, D.; Zarin, D. Temporal variability of forest fires in eastern Amazonia. Ecol. Appl. 2011, 21, 2397-2412. [CrossRef]

64. De Moura, Y.M.; Hilker, T.; Lyapustin, A.I.; Galvão, L.S.; dos Santos, J.R.; Anderson, L.O.; de Sousa, C.H.R.; Arai, E. Seasonality and drought effects of Amazonian forests observed from multi-angle satellite data. Remote Sens. Environ. 2015, 171, 278-290. [CrossRef]

65. Samanta, A.; Ganguly, S.; Vermote, E.; Nemani, R.R.; Myneni, R. Why Is Remote Sensing of Amazon Forest Greenness So Challenging? Earth Interactions 2012, 16, 1-14. [CrossRef]

66. Bi, J.; Myneni, R.; Lyapustin, A.; Wang, Y.; Park, T.; Chi, C.; Yan, K.; Knyazikhin, Y. Amazon Forests' Response to Droughts: A Perspective from the MAIAC Product. Remote Sens. 2016, 8, 356. [CrossRef]

67. Lyapustin, A.; Wang, Y.; Laszlo, I.; Kahn, R.; Korkin, S.; Remer, L.; Levy, R.; Reid, J.S. Multiangle implementation of atmospheric correction (MAIAC): 2. Aerosol algorithm. J. Geophys. Res. Space Phys. 2011, 116. [CrossRef]

68. Dalagnol, R.; Wagner, F.H.; Galvão, L.S.; Nelson, B.W.; Aragão, L.E.O.E.C.D. Life cycle of bamboo in the southwestern Amazon and its relation to fire events. Biogeosciences 2018, 15, 6087-6104. [CrossRef]

69. Myneni, R.; Hall, F.; Sellers, P.; Marshak, A. The interpretation of spectral vegetation indexes. IEEE Trans. Geosci. Remote Sens. 1995, 33, 481-486. [CrossRef]

70. Barlow, J.; Peres, C.A.; Lagan, B.O.; Haugaasen, T. Large tree mortality and the decline of forest biomass following Amazonian wildfires. Ecol. Lett. 2002, 6, 6-8. [CrossRef]

71. Cochrane, M.A. Fire science for rainforests. Nature 2003, 421, 913-919. [CrossRef]

72. Cochrane, M.A.; Schulze, M.D. Fire as a recurrent event in tropical forests of the eastern Amazon: Effects on forest structure, biomass, and species composition. Biotropica 1997, 31, 2-16. [CrossRef] 
73. Dias, M.A.F.S.; Rutledge, S.; Nobre, C.; Dolman, A.J.; Zipser, E.; Manzi, A.O.; Rocha, H.R.; Plana-Fattori, A.; Sá, L.D.A.; Alvalá, R.C.S.; et al. Cloud and rain processes in a biosphere-atmosphere interaction context in the Amazon Region. J. Geophys. Res. Space Phys. 2002, 107, LBA 39-1. [CrossRef]

74. Fornacca, D.; Ren, G.; Xiao, W. Performance of Three MODIS Fire Products (MCD45A1, MCD64A1, MCD14ML), and ESA Fire_CCI in a Mountainous Area of Northwest Yunnan, China, Characterized by Frequent Small Fires. Remote Sens. 2017, 9, 1131. [CrossRef]

75. Junior, C.H.L.S.; Pessôa, A.C.M.; Carvalho, N.S.; Reis, J.B.C.; Anderson, L.O.; Aragão, L.E.O.C. The Brazilian Amazon deforestation rate in 2020 is the greatest of the decade. Nat. Ecol. Evol. 2021, 5, 144-145. [CrossRef]

76. Liu, Y.Y.; Evans, J.P.; McCabe, M.F.; De Jeu, R.A.M.; Van Dijk, A.I.J.M.; Su, H. Influence of cracking clays on satellite estimated and model simulated soil moisture. Hydrol. Earth Syst. Sci. 2010, 14, 979-990. [CrossRef]

77. Bousquet, E.; Mialon, A.; Rodriguez-Fernandez, N.; Prigent, C.; Wagner, F.H.; Kerr, Y.H. Influence of surface water variations on VOD and biomass estimates from passive microwave sensors. Remote Sens. Environ. 2021, 257, 112345. [CrossRef]

78. Morgan, W.T.; Darbyshire, E.; Spracklen, D.V.; Artaxo, P.; Coe, H. Non-deforestation drivers of fires are increasingly important sources of aerosol and carbon dioxide emissions across Amazonia. Sci. Rep. 2019, 9, 16975. [CrossRef]

79. Withey, K.; Berenguer, E.; Palmeira, A.F.; Espírito-Santo, F.D.B.; Lennox, G.D.; Silva, C.V.J.; Aragão, L.E.O.C.; Ferreira, J.; França, F.; Malhi, Y.; et al. Quantifying immediate carbon emissions from El Niño-mediated wildfires in humid tropical forests. Philos. Trans. R. Soc. B Biol. Sci. 2018, 373, 20170312. [CrossRef] [PubMed]

80. Silva, C.V.J.; Aragão, L.E.O.C.; Young, P.J.; Espirito-Santo, F.; Berenguer, E.; Anderson, L.O.; Brasil, I.; Pontes-Lopes, A.; Ferreira, J.; Withey, K.; et al. Estimating the multi-decadal carbon deficit of burned Amazonian forests. Environ. Res. Lett. 2020, 15, 114023. [CrossRef] 